\title{
Impacto de la motivación en el rendimiento laboral. Caso de la compañía Cinépolis Sahuayo, México
}

The impact of motivation on work performance.

Case study of the company Cinépolis Sahuayo, Mexico.

Impacto da motivação no rendimento laboral.

Caso da companhia: Cinépolis Sahuayo, México

\author{
José Guadalupe Vargas Hernández \\ Departamento de Administración, Centro \\ Universitario de Ciencias Económico- \\ Administrativas, Universidad de \\ Guadalajara, México. \\ E-mail: josevargas@cucea.udg.mx
}

Juan Luis González Díaz

Tecnológico Nacional de México/l. T.

Jiquilpan, Jiquilpan de Juárez,

Michoacán, México.

E-mail: juanito-0696@live.com.mx
Gabriela Muratalla-Bautista Departamento de Ciencias EconómicoAdministrativas, Tecnológico Nacional de México/l. T. Valle de Morelia, Morelia, Michoacán, México.

E-mail:gmuratalla@itvallemorelia.edu.mx
Fecha de recepción: 30/01/2018 Fecha de aceptación: 15/05/2018
Palabras Clave

- desempeño laboral

- industria cinematográfica

- motivación

\section{Resumen}

El objetivo del presente artículo es analizar el impacto que tiene la motivación en el rendimiento laboral de Cinépolis Plaza Feria Sahuayo, a partir de la revisión de la literatura teórica y empírica. Metodológicamente se realizó un estudio descriptivo y explicativo que describe los conceptos relacionados con los elementos antes mencionados y se explica la relación de las variables sujetas de estudio la independiente es la motivación y la dependiente el rendimiento laboral. La investigación es mixta, ya que se conforma de una parte cualitativa y otra de carácter cuantitativo, de tipo correlacional. Los principales resultados que se obtienen son las correlaciones de Pearson de 0.698 entre las variables, en los indicadores capacitación con expectativas 0.892 y providencia de la recompensa con incentivos 0.825 . Se concluye que el impacto que tiene la motivación en el rendimiento laboral es significativo por presentar una correlación 
Palabras clave

- work performance

- film industry

- motivation positiva considerable. Además se determinan los indicadores que tienen mayor impacto, la capacitación con las expectativas y la providencia de la recompensa con los incentivos.

\begin{abstract}
The aim of this article is to analyze the impact of motivation on work performance in Cinépolis Plaza Feria Sahuayo, based on a review of the theoretical and empirical literature. As regards methodology, a descriptive and explanatory study that describes the concepts related to the aforementioned elements and explains the relationship of the variables subject to study was carried out. The independent variable under study is motivation whereas the dependent one is work performance. The research is mixed, since it includes a qualitative and a quantitative part, the latter being correlational. The main results obtained are: the Pearson correlations of 0.698 among the variables, in the training indicators with expectations 0.892 and providence of the reward with 0.825 incentives. Conclusions show that the impact of motivation on work performance is significant because there is a considerable positive correlation. Moreover, it has been found that the indicators which have the greatest impact are training with expectations and the providing of reward with incentives.
\end{abstract}

\section{Resumo}

0 objetivo do presente artigo é analisar o impacto que tem a motivação no rendimento laboral da Cinépolis Plaza Feria Sahuayo, a partir da revisão da literatura teórica e empírica. Metodologicamente realizou-se um estudo descritivo e explicativo que descreve os conceitos relacionados com os elementos antes citados e explica-se a relação das variáveis de estudo, a independente é a motivação e a dependente é o rendimento laboral. A pesquisa é mista, já que conforma-se de uma parte qualitativa e outra de caráter quantitativo, do tipo correlacional. Dentro dos principais resultados que se obtém são as correlações de Pearson de 0.698 entre as variáveis, nos indicadores capacitação com expectativas 0.892 e providência da recompensa com incentivos 0.825 . Conclui-se que o impacto que tem a motivação no rendimento laboral é significativo por apresentar uma correlação positiva considerável, aliás determinam-se os indicadores que têm maior impacto, a capacitação com as expectativas e a providência da recompensa com os incentivos. 